\title{
Compost Barns for Dairy Cows-Aspects of Animal Welfare
}

\author{
E. Ofner-Schröck ${ }^{1 *}$, M. Zähner², G. Huber¹, K. Guldimann², T. Guggenberger¹, \\ J. Gasteiner ${ }^{1}$ \\ ${ }^{1}$ HBLFA Raumberg-Gumpenstein, Agricultural Research \& Education Centre, Irdning, Austria \\ ${ }^{2}$ Institute for Sustainability Sciences (ISS), Ettenhausen, Switzerland \\ Email: ${ }^{*}$ Elfriede.Ofner-Schroeck@raumberg-gumpenstein.at
}

Received 17 February 2015; accepted 28 March 2015; published 1 April 2015

Copyright (C) 2015 by authors and Scientific Research Publishing Inc.

This work is licensed under the Creative Commons Attribution International License (CC BY). http://creativecommons.org/licenses/by/4.0/

(c)

\section{Abstract}

Compost barns for dairy cows are showing increased popularity also in Central Europe. A compost barn is used mainly as a two-area system with a bedded lying area and a solid feeding alley. Sawdust or dry fine wood shavings or wood chips are mostly used as bedding material, which has to be stirred twice a day. Stirring aerates and mixes faeces and urine into the bedding material, the mixture decomposes by means of aerobic microorganisms. A joint research project between the Agricultural Research and Education Centre Raumberg-Gumpenstein (HBLFA) and the Institute for Sustainability Sciences Tänikon (ISS) analyzed amongst other things, the cleanliness of the animals, integument alterations, lying behaviour and the current lameness situation of animals. A total of 138 cows were examined on five Austrian dairy farms. All cows were visually scored and animal behaviour was observed by data loggers as well as by direct observation. The mean value concerning cleanliness of animals was 0.44 , while the udder was the cleanest and the lower leg the dirtiest area. Only a few lesions in carpal and tarsal joints could be found. Cows showed no differences in lying behaviour between times of day and temperatures. Large differences in lying behaviour were evident among farms. While on the compost barn farms only around $25 \%$ of all cows were scored to be lame, on cubicle-housing system farms $31 \%-46 \%$ of the cows fell into that category $(p<0.001)$. From the present results, the compost barn can be seen as an animal-friendly system. In further investigations other factors affecting animal health and to resolve any outstanding issues concerning economy and alternative litter materials should be analyzed.

\section{Keywords}

Compost Barn, Cattle, Dairy Cows, Behaviour, Cleanliness, Lameness

\footnotetext{
${ }^{*}$ Corresponding author.
}

How to cite this paper: Ofner-Schröck, E., Zähner, M., Huber, G., Guldimann, K., Guggenberger, T. and Gasteiner, J. (2015) Compost Barns for Dairy Cows-Aspects of Animal Welfare. Open Journal of Animal Sciences, 5, 124-131. 


\section{Introduction}

Compost barns for dairy cows are also becoming more and more popular in Central Europe. They have already been successfully built and operated for quite some time in Israel and America. A lot of the scientific findings currently available on this kind of housing system come from America, especially Minnesota [1]-[5].

A compost barn is used mainly as a two-area system with a bedded lying area and a feeding alley, which can have either a solid or a slatted floor. Regarding bedding, good experience has been gained in Austria with sawdust and wood shavings. Starting with a bed approximately 20 to $25 \mathrm{~cm}$ high $\left(1.8-2.5 \mathrm{~m}^{3} / \mathrm{animal}\right)$, about 0.4 to $1.3 \mathrm{~m}^{3} /$ animal is added every 2 to 7 weeks $\left(10-15 \mathrm{~m}^{3} /\right.$ animal and year). The bedding material is loosened once or twice a day with a grubber or rotary hoe to a depth of 20 to $25 \mathrm{~cm}$, working in any faeces and urine. This lets air into the bedding so that the mixture can decompose with the help of aerobic micro-organisms [6]. The result is a loose, friable bedding material. Its temperature should be between $30^{\circ} \mathrm{C}$ and $45^{\circ} \mathrm{C}$ in order to quickly convert the organic substance and kill off undesirable germs while supporting beneficial germs [7]. As far as possible, new bedding should not be started during the winter months because it is difficult for the rotting process to begin in the cold. The lying area may be separated from the feeding alley by walls or it may be placed about 30 to 50 $\mathrm{cm}$ lower. Compost removal (mucking out) is performed twice a year (in spring and autumn) when the compost bedding has reached a thickness of 50 to $60 \mathrm{~cm}$. The size of the lying area is of crucial importance not only for the cleanliness and wellbeing of the animals but also for the efficiency of the housing system. While in Israel there is an area of between 13 and $20 \mathrm{~m}^{2}$ for each animal, in the USA the lying areas are 7.5 to $9.2 \mathrm{~m}^{2}$ per cow [8]. With regard to the size of lying area, the division of space and the management (bedding, and dung removal), the systems commonly used in Austria are more similar to the American system. Positive effects on efficiency are seen with simple structures with low construction costs and a relatively small amount of working hours needed to care for the lying areas. However, the availability of cheap bedding materials is of great importance with regard to the efficiency of the compost housing system. Economical sources of supply have to be found on individual farms, and further research work has to be performed on alternative bedding materials. In any case, the compost barn can be considered as an interesting system for grassland farms without a great deal of straw available.

\section{Materials and Methods}

A joint research project between the Agricultural Research and Education Centre Raumberg-Gumpenstein (HBLFA) and the Institute for Sustainability Sciences Tänikon (ISS) analyzed the overall conditions involved in the construction and running of compost barns for dairy farming. Amongst other things, the integument alterations, cleanliness of the animals, lying behaviour and the current lameness situation of animals were examined.

Investigations into animal behaviour, cleanliness of the animals, integument alterations and lameness assessments were performed on five Austrian farms with compost barns in Upper Austria and Styria. A total of 138 cows were examined. The herd size on the farms varied between 18 and 35 cows. Another two farms in Upper Austria were included in a questionnaire survey, so a total of seven farms with compost barns.

\subsection{Animal Behaviour}

The place selected by the animals for lying and standing was investigated by direct observation. On each farm, on two days, the behaviour of 10 focus animals was recorded during the periods from 10:30 to 12:30 hrs and from 14:00 to 16:00 hrs, in 5-minute intervals. It was noted whether and where the animals were lying-on the edge (near the outside wall, near the inside wall), in the centre or outside of the lying area. The places found for standing at the particular time was also documented.

\subsection{Cleanliness of the Animals}

The cleanliness of the animals was assessed using the model devised by Faye and Barnouin [9] on all of the animals in the herd. With this model, the animals are assessed on five areas of the body (zones) with five scores ( 0 $=$ no dirt to $2=$ totally dirty or covered with thick plaques of dirt):

Zone 1: Area between the base of the tail, the ischial tuberosity and the area of the suspensory apparatus of udder;

Zone 2: Udder viewed from behind; 
Zone 3: Lower hind leg (area of the tarsus to the dewclaw);

Zone 4: Udder viewed from the side;

Zone 5: Upper hind leg (excluding the tarsus).

\subsection{Integument Alterations (Hairless Patches, Lesions, Swellings)}

The integument alterations were also assessed with all of the animals in the herd, using the system devised by Ekesbo [10]. The assessment was limited to the carpus, tarsus and the tarsal joint. The examination included hairless patches, dry scabs and open wounds (according to size) and swellings.

\subsection{Lameness}

In this project the animals were assessed according to a model developed by Winckler and Willen [11], in which the degree of lameness was classified according to five scores (values):

Score 1: Normal gait;

Score 2: Uneven gait;

Score 3: Short striding gait with one limb;

Score 4: Short striding gait with more than one limb or strong reluctance to bear weight on one limb;

Score 5: Does not support on one limb or strong reluctance to put weight on limb in two or more limbs.

Before being assessed, the cows were locked in the feeding rack and then released individually and assessed while walking in the feeding alley.

\subsection{Statistical Analysis}

The data were analyzed with Microsoft Excel and the statistics software packages R and Statgraphics Centurion.

\section{Results and Discussion}

This article gives selected results from the research project entitled "Overall conditions for the use of compost barns in dairy farming" ("Rahmenbedingungenfür den Einsatz von Kompostställen in der Milchviehhaltung"). A full indication of all of the results is given in the final report on that project [12].

\subsection{Animal Behaviour}

The proportions of cows standing and lying show that, in addition to the differences between morning and afternoon, the great differences are mainly between farms (Table 1). Within the present temperature range it was not possible to observe any connection between the temperature and the proportion of cows lying. Even at higher temperatures no avoidance of the lying areas could be discerned. Furthermore, the lying area was very seldom used for standing and only by a few animals. Regarding the location selected for lying, there were no differences between morning and afternoon (Figure 1). Here the differences between farms were much greater, too. The choice of lying locations and the overall lying behaviour were greatly influenced by the structural arrangement and the shape of the lying area (long and narrow to short and wide). The open construction with good ventilation in all farms allowed for a good stable climate even in high temperatures. Zähner [13] was able to show in investigations that cows prefer open lying areas in summer and more protected areas in winter.

\subsection{Cleanliness of the Animals}

Table 2 summarizes the results on cleanliness of the animal. The mean value across all zones was 0.44 . The most dirty area of the body was zone 3 (lower hind leg) with an average score of 0.80 ; the least dirtiness was in zone 4 (udder seen from the side) with an average score of 0.19. As shown in Figure 2, the cleanliness of the animals in compost barns is comparable with other housing systems [14] [15]. Hörning [16] found an average dirtiness of 0.40 (54 farms) in cubicle housing systems, 0.59 (30 farms) in deep-litter systems and 0.77 (29 farms) in sloped-floor systems, but stressed the high levels of variation within one system.

The animals in the compost barn display a good level of cleanliness. The greater degree of dirtiness in the area of the lower leg is probably incurred mostly in the feeding alleys. The very low level of dirtiness on the udder is a positive observation with regard to udder health, because a dirty udder is in particular connected with 
Table 1. Proportion of standing and lying cows and temperature in the two-day period on the five farms with compost barns examined.

\begin{tabular}{|c|c|c|c|c|c|c|c|c|c|c|}
\hline \multirow{2}{*}{ Period } & \multirow{2}{*}{ Farm } & \multicolumn{3}{|c|}{ Proportion of standing animals [\%] } & \multicolumn{3}{|c|}{ Proportion of lying animals [\%] } & \multicolumn{3}{|c|}{ Temperature $\left[{ }^{\circ} \mathrm{C}\right]$} \\
\hline & & Average & Min. & Max. & Average & Min. & Max. & Average & Min. & Max. \\
\hline \multirow{5}{*}{ Morning } & 1 & 76.4 & 46.4 & 100.0 & 23.6 & 0.0 & 53.6 & 16.5 & 16.1 & 16.9 \\
\hline & 2 & 45.3 & 13.0 & 100.0 & 54.7 & 0.0 & 87.0 & 15.4 & 12.9 & 18.5 \\
\hline & 3 & 51.8 & 31.3 & 78.8 & 48.2 & 21.2 & 68.8 & 19.8 & 17.0 & 22.4 \\
\hline & 4 & 42.8 & 10.0 & 90.0 & 57.2 & 10.0 & 90.0 & 20.9 & 19.6 & 25.0 \\
\hline & 5 & 59.8 & 10.0 & 100.0 & 40.2 & 0.0 & 90.0 & 20.4 & 19.1 & 26.0 \\
\hline \multirow{5}{*}{ Afternoon } & 1 & 36.5 & 10.7 & 64.3 & 63.5 & 35.7 & 89.3 & 19.0 & 17.5 & 21.3 \\
\hline & 2 & 22.6 & 0.0 & 100.0 & 77.4 & 0.0 & 100.0 & 17.6 & 13.9 & 22.2 \\
\hline & 3 & 69.6 & 33.3 & 100.0 & 30.4 & 0.0 & 66.7 & 21.1 & 18.8 & 23.9 \\
\hline & 4 & 55.5 & 30.0 & 80.0 & 44.5 & 20.0 & 70.0 & 22.5 & 21.2 & 24.0 \\
\hline & 5 & 71.5 & 40.0 & 100.0 & 28.5 & 0.0 & 60.0 & 21.7 & 20.7 & 22.6 \\
\hline
\end{tabular}

Table 2. Dirtiness of the animals broken down according to farms and zones (areas of the body).

\begin{tabular}{|c|c|c|c|c|c|c|c|c|}
\hline \multirow{3}{*}{ Farm } & \multirow{3}{*}{$\begin{array}{l}\text { Number of } \\
\text { animals }\end{array}$} & \multicolumn{6}{|c|}{ Dirtiness (mean values) } & \multirow{3}{*}{$\begin{array}{c}\text { Total for } \\
\text { zones (index) }\end{array}$} \\
\hline & & \multicolumn{5}{|c|}{ Zone } & \multirow{2}{*}{$\begin{array}{l}\text { Mean value } \\
\text { for all zones }\end{array}$} & \\
\hline & & Base of tail & Rear of udder & Lower leg & Side of udder & Upper leg & & \\
\hline 1 & 27 & 0.70 & 0.26 & 1.26 & 0.26 & 0.81 & 0.66 & 3.29 \\
\hline 2 & 23 & 0.72 & 0.41 & 1.04 & 0.30 & 0.37 & 0.57 & 2.84 \\
\hline 3 & 32 & 0.50 & 0.25 & 0.56 & 0.14 & 0.14 & 0.32 & 1.59 \\
\hline 4 & 18 & 0.21 & 0.16 & 0.26 & 0.08 & 0.21 & 0.18 & 0.92 \\
\hline 5 & 35 & 0.51 & 0.29 & 0.79 & 0.19 & 0.41 & 0.44 & 2.19 \\
\hline $\begin{array}{l}\text { Mean value } \\
\text { for all cows }\end{array}$ & $\mathrm{n}=135$ & 0.54 & 0.28 & 0.80 & 0.19 & 0.39 & 0.44 & 2.17 \\
\hline
\end{tabular}

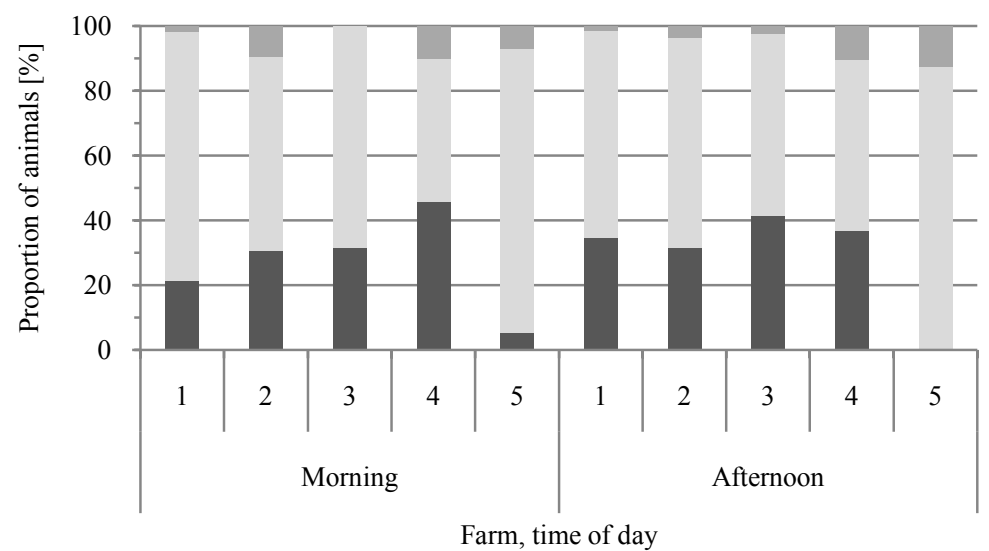

$\square$ Edge $\quad$ Centre $\square$ Other

Figure 1. Proportion of cows lying in different areas of the lying areaedge, centre, and others. 


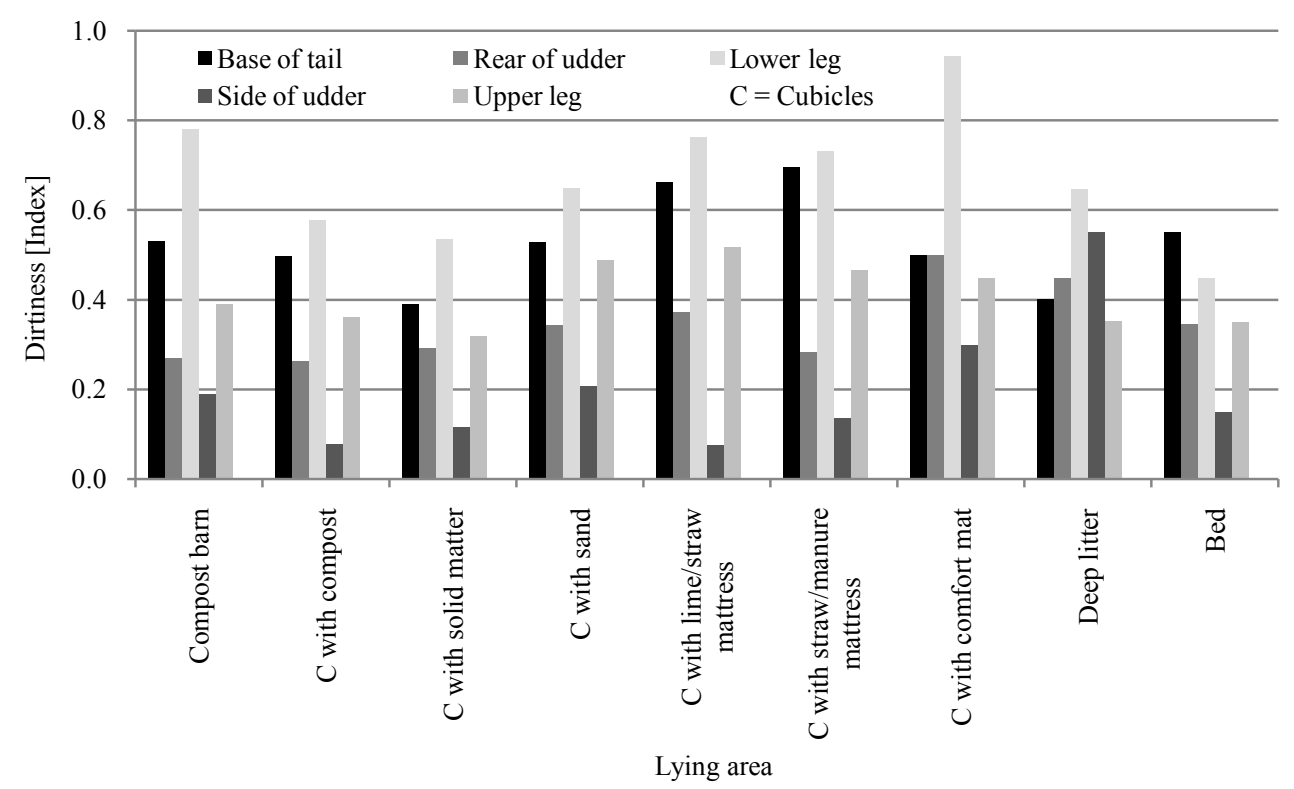

Figure 2. Dirtiness of the animals in different housing systems (comparative values on compost barns from [14] [15]).

a high risk of infection with pathogens [17]. Influences specific to individual farms, such as stocking density, as well as the management of the compost barn for instance the frequency of providing fresh bedding and dung removal (compost removal), bedding material and amount of bedding as well as the "consistency" of the animals' faeces should be taken into account when interpreting the dirtiness of the animals.

\subsection{Integument Alterations}

In the farms with compost barns investigated, there were only slight integument alterations in the animals $(\mathrm{n}=$ 135). Hairless patches $<2 \mathrm{~cm}$ appear on average in 9.6\% of all cows (Max.: 25.9\%; Min.: 2.2\%). Hairless patches $>2 \mathrm{~cm}$ could be seen on average in $2.2 \%$ of all cows (Max.: $12.6 \%$; Min.: $0 \%$ ). Dry scabs $<2 \mathrm{~cm}$ appear on average in $0.7 \%$ of all cows (Max.: $4.4 \%$; Min.: $0 \%$ ). There was swelling on only one cow and no open wounds could be detected. Comparing the proportion of animals with an intact hair coat (no integument alteration) on the joints with values from other housing systems gives the image shown in Table 3. The extent of various integument alterations in different housing systems $(\mathrm{p}<0.001)$ is shown in Figure 3.

In the compost barn an average of $82.6 \%$ of all of the animals displayed an intact hair coat (no integument alteration) on the joints. According to the aforementioned authors, this is a value that is comparable with a cubicle housing system with straw-manure mattress $(86.2 \%)$. The investigation performed by Barberg et al. [1] on animal welfare in compost barns in Minnesota (USA) there were alterations to the tarsus in $25 \%$ of the animals ( $\mathrm{n}=$ 796). In that case, $24 \%$ of the animals had hairless patches and the remaining $1 \%$ of the animals had swellings. No alterations were found in seven out of twelve herds.

\subsection{Lameness}

If we consider all of the cows observed $(\mathrm{n}=138), 42.0 \%$ display a score of $1 ; 31.9 \%$ a score of $2 ; 16.7 \%$ a score of 3; $6.5 \%$ a score of 4 and $2.2 \%$ a score of 5 (Figure 4). In further analysis, to have a better overview and be able to compare the values with the data in the literature, scores $3+4+5$ were classed together as "lame" and 1 +2 as "not lame" (Table 4). In all of the cows observed $(\mathrm{n}=138), 73.9 \%$ could be classified as "not lame" and $25.4 \%$ as "lame". These are compared with values from lameness assessments that were performed using exactly the same methodology in ten cubicle housing systems in Styria [20]. In all of the cows observed in that case ( $\mathrm{n}=175), 54.3 \%$ could be classified as "not lame" and $45.7 \%$ as "lame". Figure 4 shows the degree of lameness found on farms with cubicle housing systems.

If we compare the results of the assessment on the five compost barn farms and the ten farms with cubicle 
Table 3. Proportion of animals with an intact hair coat (no integument alteration) on the joints in different housing systems [\%] (comparative values on compost barn from [15] [18] [19]).

\begin{tabular}{|c|c|c|c|c|}
\hline & Mean value & Standard deviation & Maximum & Minimum \\
\hline Compost barn & 82.6 & 18.6 & 97.1 & 52.2 \\
\hline Cubicles with compost & 59.3 & 10.4 & 66.7 & 52.0 \\
\hline Cubicles with solid matter & 59.3 & 13.1 & 72.3 & 462 \\
\hline Cubicles with sand & 52.3 & 11.4 & 65.0 & 37.5 \\
\hline Cubicles with lime-straw mattress & 78.2 & 9.8 & 82.0 & 58.0 \\
\hline Cubicles with straw-manure mattress & 86.2 & 10.6 & 95.0 & 68.2 \\
\hline Cubicles with loose straw & 32.1 & 33.9 & 76.5 & 0.0 \\
\hline Cubicles with comfort mat & 14.6 & 14.3 & 44.4 & 0.0 \\
\hline Cubicles with rubber mat & 9.8 & 6.2 & 18.8 & 4.8 \\
\hline
\end{tabular}

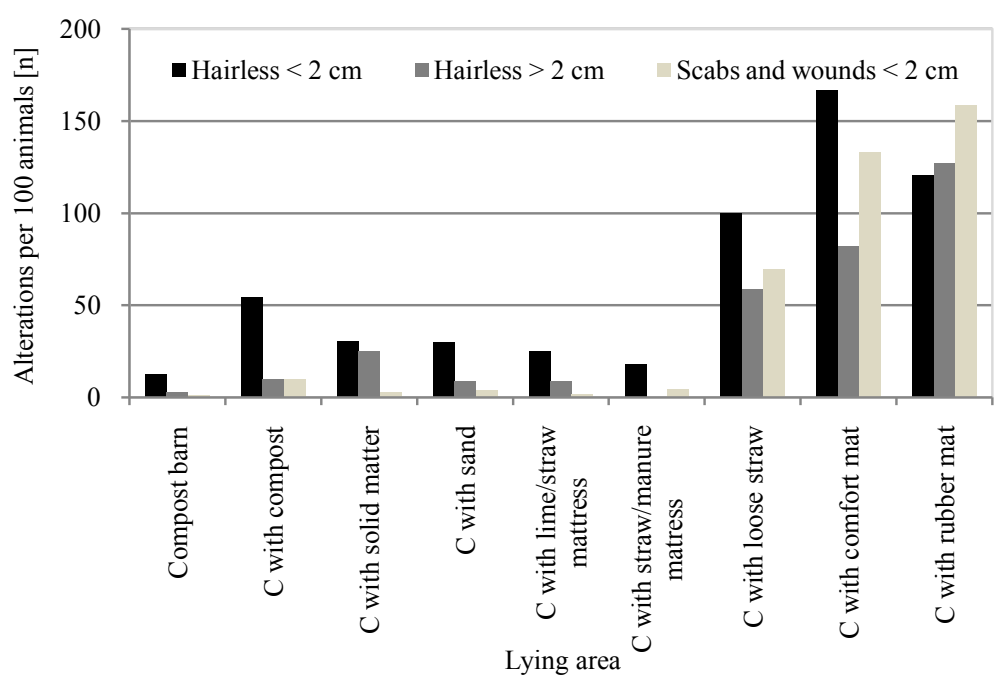

Figure 3. Animals with alterations to the joints in different housing systems (comparative values on compost barn from [15] [18] [19]).

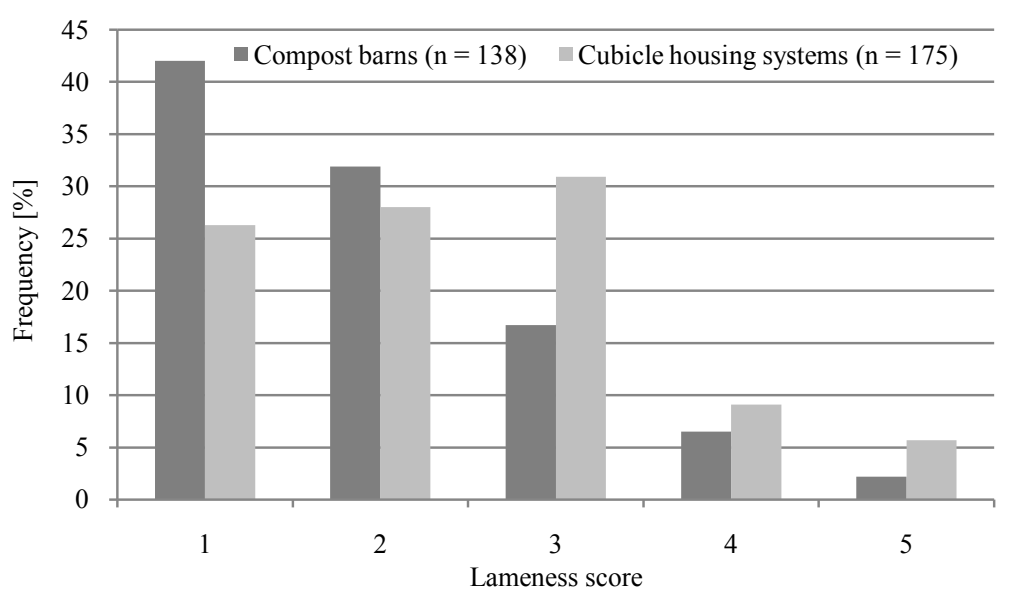

Figure 4. Degree of lameness in all of the cows $(n=138)$ on the farms with compost barns investigated compared to the degree of lameness in all of the cows $(n=175)$ in the farms with cubicle housing systems investigated according to Ofner-Schröck et al. [20]. 


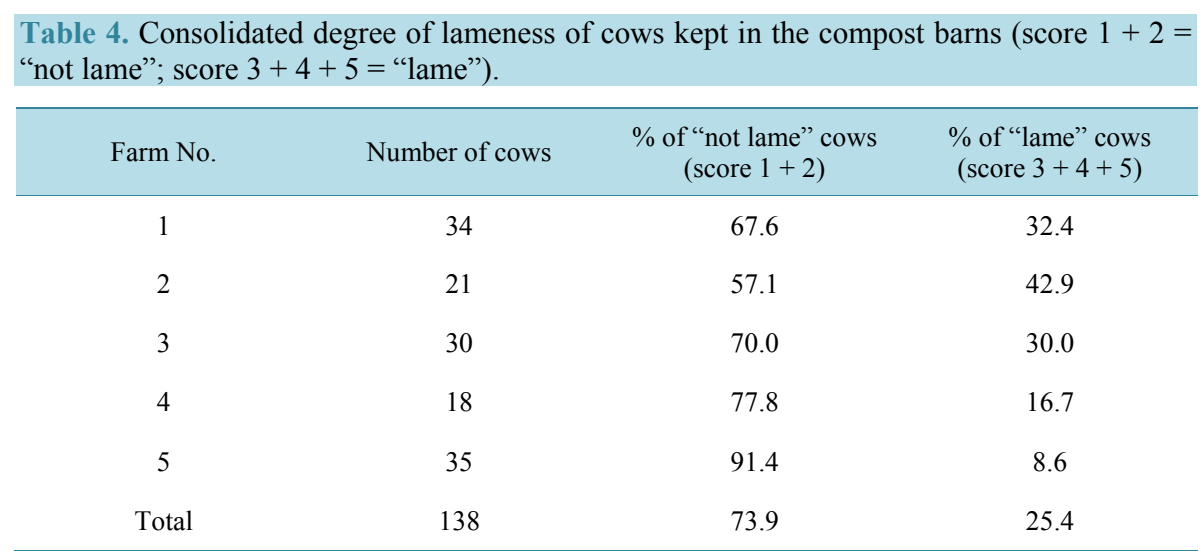

housing systems, significant differences appear in the number of lame cows $(\mathrm{p}<0.001)$. While on the compost barn farms only around $25 \%$ of all cows were classed as "lame", on the cubicle-housing system farms around $46 \%$ fell into that category. Continuing investigations to analyze other influencing factors (e.g. feeding, claw trimming) and to increase the sample should be sought. Investigations by other authors on Austrian farms with cubicle housing systems showed a proportion of $31 \%$ lame animals (sample size $=30$ farms [21]) and $36 \%$ lame animals (sample size $=80$ farms [22]). In the investigation performed by Barberg et al. [1] in compost barns in Minnesota (USA), 7.8\% of the animals $(\mathrm{n}=793)$ displayed clinical lameness using the five-stage system established by Sprecher et al. [23]. There were no lame cows to be found in two out of twelve herds.

\section{Conclusion}

From the present results, the compost barn can be seen as an animal-friendly system. Further investigations are desirable to analyze other factors affecting animal health and to resolve any outstanding issues concerning economy and alternative litter materials.

\section{Acknowledgements}

We would like to thank the farmers for their participation and support to this study. We thank the colleagues from the extension service for agricultural buildings of the Austrian provinces for the good cooperation. Additionally, we thank the employees of the HBLFA Raumberg-Gumpenstein and ISS Tänikon for their input in data collection and analysis.

\section{References}

[1] Barberg, A.E., Endres, M.I., Salfer, J.A. and Reneau, J.K. (2007) Performance and Welfare of Dairy Cows in an Alternative Housing System in Minnesota. Journal of Dairy Science, 90, 1575-1583. http://dx.doi.org/10.3168/jds.S0022-0302(07)71643-0

[2] Barberg, A.E., Endres, M.I. and Janni, K.A. (2007) Compost Dairy Barns in Minnesota: A Descriptive Study. Applied Engineering in Agriculture, American Society of Agricultural and Biological Engineers, 23, 231-238.

[3] Endres, M.I. and Barberg, A.E. (2007) Behavior of Dairy Cows in an Alternative Bedded-Pack Housing System. Journal of Dairy Science, 90, 4192-4200. http://dx.doi.org/10.3168/jds.2006-751

[4] Espejo, L.A., Endres, M.I. and Salfer, J.A. (2006) Prevalence of Lameness in High-Producing Holstein Cows Housed in Freestall Barns in Minnesota. Journal of Dairy Science, 89, 3052-3058. http://dx.doi.org/10.3168/jds.S0022-0302(06)72579-6

[5] Janni, K.A., Endres, M.I., Reneau, J.K. and Schoper, W.W. (2007) Compost Dairy Barn Layout and Management Recommendations. Applied Engineering in Agriculture, American Society of Agricultural and Biological Engineers, 23, $97-102$.

[6] Holzeder, S. (2011) Kompoststall—eine Alternative stellt sich vor. In: Tagungsbandzur Bautagung Raumberg-Gumpenstein 2011, HBLFA Raumberg-Gumpenstein, Irdning, 5-6. http://www.raumberg-gumpenstein.at

[7] Holzeder, S. (2012) Komfort zum Wohlfühlen. Elite, 3, 54-59.

[8] Leifker, A. (2010) Grenzenlose Freiheit? Top Agrar, 4, R6-R10. 
[9] Faye, B. and Barnouin, J. (1985) Objectivation de la propreté des vaches laitières et des stabulations - L'indice de propreté. Bulletin Technique C.R.Z.V. Theix, INRA, 59, 61-67.

[10] Ekesbo, I. (1984) Methoden der Beurteilung von Umwelteinflüssen auf Nutztiere unter besonderer Berücksichtigung der Tiergesundheit und des Tierschutzes. Wien. Tierärztliche Monatsschrift, 71, 186-190.

[11] Winckler, C. and Willen, S. (2001) The Reliability and Repeatability of a Lameness Scoring System for Use as an Indicator of Welfare in Dairy Cattle. Acta Agriculturae Scandinavica, Section A-Animal Science, Suppl. 30, 103-107.

[12] Ofner-Schröck, E., Zähner, M., Huber, G., Guldimann, K., Guggenberger, T. and Gasteiner, J. (2014) Rahmenbedingungen für den Einsatz von Kompostställen in der Milchviehhaltung. Final Report, HBLFA Raumberg-Gumpenstein, Irdning. http://www.raumberg-gumpenstein.at

[13] Zähner, M. (2001) Beurteilung von Minimalställen für Milchvieh anhand ethologischer und physiologischer Parameter. Dissertation ETH, Zürich.

[14] Keck, M., Zähner, M. and Hauser, R. (2004) Minimalställe für Milchkühe bewähren sich: Empfehlungen für die Planung und den Betrieb. FAT Report No. 620, Forschungsanstalt Agroscope Reckenholz-Tänikon ART.

[15] Zähner, M., Schmidtko, J., Schrade, S., Sachaeren, W. and Otten, S. (2009) Alternative Einstreumaterialien in Liegeboxen. In: Tagungsband Bautagung Raumberg-Gumpenstein 2009, HBLFA Raumberg-Gumpenstein, 33-38. http://www.raumberg-gumpenstein.at

[16] Hörning, B. (2003) Nutztierethologische Untersuchungen zur Liegeplatzqualität in Milchviehlaufstallsystemen unter besonderer Berücksichtigung eines epidemiologischen Ansatzes. Postdoctoral Thesis (Habilitationsschrift), Universität Kassel, Witzenhausen.

[17] Schreiner, D.A. and Ruegg, P.L. (2003) Relationship between Udder and Leg Hygiene Scores and Subclinical Mastitis. Journal of Dairy Science, 86, 3460-3465. http://dx.doi.org/10.3168/jds.S0022-0302(03)73950-2

[18] Buchwalder, T. (1999) Einfluss der Liegeplatzqualität auf das Verhalten und die Schäden bei Milchkühen im Boxenlaufstall. Interner Schlussbericht, Tänikon.

[19] Schaub, J., Friedli, K. and Wechsler, B. (1999) Weiche Liegematten für Milchvieh-Boxenlaufställe-Strohmatratzen und sechs Fabrikate von weichen Liegematten im Vergleich. FAT Reports No. 529, Tänikon.

[20] Ofner-Schröck, E., Gasteiner, J., Guggenberger, J., Mösenbacher-Molterer, I., Häusler, J., Krimberger, B., Zainer, I., Zainer, J., Finotti, E. and Bachler, C. (2009) Vergleich der Bewertung der Tiergerechtheit von Rinderhaltungssystemen mit dem Tiergerechtheitsindex TGI 35 L und mit Hilfe von ethologischen und tiergesundheitlichen Parametern. Final Report Project No. BAL 03 2324, HBLFA Raumberg-Gumpenstein, Irdning.

[21] Dippel, S., Dolezal, M., Brenninkmeyer, C., Brinkmann, J., March, S., Knierim, U. and Winckler, C. (2009) Risk Factors for Lameness in Cubicle Housed Austrian Simmental Dairy Cows. Preventive Veterinary Medicine, 90, $102-112$. http://dx.doi.org/10.1016/j.prevetmed.2009.03.014

[22] Mülleder, C. and Waiblinger, S. (2004) Analyse der Einflussfaktoren auf Tiergerechtheit, Tiergesundheit und Leistung von Milchkühen im Boxenlaufstall auf konventionellen und biologischen Betrieben unter besonderer Berücksichtigung der Mensch-Tier-Beziehung. Endberichtzum Forschungsprojekt 1267, Eigenverlag Wien, 184 p.

[23] Sprecher, D.J., Hostetler, D.E. and Kaneene, J.B. (1997) A Lameness Scoring System that Uses Posture and Gait to Predict Dairy Cattle Reproductive Performance. Theriogenology, 47, 1179-1187. http://dx.doi.org/10.1016/S0093-691X(97)00098-8 